\title{
Influence of Tourism on the Employment in Vojvodina
}

\section{Anđelija Ivkov, Aleksandra Dragin, Tamara Kovačević, Branislav Đurđev, Ljubica Ivanović}

\begin{abstract}
Certain changes in the economic structure happen as part of the economic development of a country or a region. Thus, the analysis of the distribution of labour force according to the type of activity is found very interesting. Job market in AP Vojvodina is characterised by high unemployment, high hidden unemployment and insufficient mobility of the labour force.

Tourism and hotel industry belong to those types of activities that have a rather elastic and complex approach towards population categories that are in possibilities to find employment in them. Different population structures are included in them. The development of tourism and hotel industry is an important precondition for lessening unemployment problems in these areas. That is because tourism and hotel industry, with their own development, activate the whole system of other complementary activities, thus solving this problem on a level of a larger spatial unity. First of all, a larger number of young people, and all those who are capable of working, should be included in the development of tourism in Vojvodina. Even older categories of population should be included as they could contribute to the development as much as they are able to. Organize different courses for domicile population from smaller places in a municipality that has certain tourist potentialities (foreign language courses, computer courses, etc.), create spatial conditions, provide technical equipment and appliances, etc.
\end{abstract}

Key words: tourism, employment, demographic transition, Vojvodina, Serbia.

Department of Geography, Tourism and Hotel Management, Faculty of Sciences, University of Novi Sad, Trg Dositeja Obradovića 3, 21000 Novi Sad, Serbia

\section{Distribution of Labour Force According to the Type of Activity}

Almost as a rule, agriculture is the main activity in economically weakly developed countries and regions. Later, parallel with economic development, the share of agriculture in forming national or regional product declines, whereas the share of industry increases. After the phase of industry expansion, its importance gradually declines, while tertiary activities gain larger importance (Kicošev, Bubalo, 1999). Currently, underdeveloped countries anticipate tourism as the initiator of their development (increase of employment, development of economy, income increase - especially foreign tourism, increase in national income, etc.).

During the period observed (19752000), the number of people engaged in agriculture in Vojvodina fell from 75.000 to 44.106 , i.e. from $15.3 \%$ to $10.6 \%$; a fact that indicates a large economic transformation of this area. However, there are still some settlements in Vojvodina dominated by people actively employed in agriculture. For example, these are in western and southeastern parts of Srem.

The share of persons employed in industry and mining constantly grows during the almost whole period and according to data from 1998. it represents $40.1 \%$ of all the activities, when its slow fall starts and in 2000 . it represents $39.7 \%$.

Financial and other services experience similar tendencies, where a share of those employed in all activities grew from $1.8 \%$ to $3.7 \%$. The same applies to education and culture where it grew from $6.6 \%$ to $9.2 \%$; whereas in healthcare and social protection it almost doubled from $5.0 \%$ to $9.07 \%$.

Since 1987. traffic, trade, civil engineering, tourism and hotel industry experience the growth in a number of employed people, while from the beginning of the 1990 s the share of these activities in a total economy of Vojvodina decreased. A negative trend of persons employed in tourism in Vojvodina is worrying since it is necessary that a much larger number of people is included in the development of tourism.

Handicraft is an economic activity that experienced negative development in a period observed. The number and share of persons employed in handicraft constantly declined and is the result of a more dynamic development of industry. This is where the downward progress is most obvious because since 1975 . from $5.9 \%$ it fell to $1.2 \%$ (year 2000).

The number and share of persons employed in administration and civil services, as well as in waterpower engineering, and also in forestry and housing-municipal activities changed only a bit during the period observed.

\section{Influence of Tourism}

Tourism and hotel industry belong to activities that basically have a rather elastic and complex approach towards population categories that are in a possibility to find employment in them. Different population structures are included in them.

The development of tourism and hotel industry is a necessary precondition for lessening employment problems in this region. That is because tourism and hotel industry, with their own development, activate the whole system of other complementary activities, thus solving this problem on a level of a larger spatial unity.

The relation between the share of persons employed in tourism and hotel industry and the total number of persons employed in economy reflects the way how we actually treat tourism and hotel industry. That is why the share of those employed in hotel industry is much higher and in certain years it is almost the only bearer of the employed labour force, while in tourism it goes up to a maximum of 0.11 and the minimum is $0.06 \%$.

It is noticeable that a number of persons employed in economy gradually grows from 1972. until the end of 1980 os, for that number to start constantly to fall from 1990s.

The change in the number of people employed in economy reflected upon the change in the number of people employed in tourism and hotel industry. The share of people employed in that activity was $2.46 \%$ at the beginning of the period, in order to reach $3.02 \%$ until the mid 1980 os. After that, its share constantly falls and in 2000 . it represents $1.58 \%$. In 2001 . it is $1.68 \%$; fact that indicates a certain growth in a number of people employed in hotel industry and 
tourism, which gives a certain hope for the development of tourism in Vojvodina.

If we separately look at hotel industry and tourism, it is noticeable that hotel industry experiences a constant fall of people employed (from $2.41 \%$ in 1972 . to $1.62 \%$ in 2001). This decline directly results from closing down a large number of objects in the public sector that are of much larger capacities and opening of smaller objects in the private sector.

The share of those employed in tourism from $0.05 \%$ at the beginning of the period grows to $0.11 \%$ at the end of 1980 ; for it to start falling again and in the last 10 years it has well-balanced values of $0.06-0.07 \%$. If this share continues to grow, tourism and hotel industry will represent an important economic activity, where a lot of people unemployed will find employment.

\section{What to do Next?}

Deficiency of strong economy, especially in rural areas, needs to be substituted by proper alternatives - employment and income as the preconditions for the survival of the community, as well as the support of the community, individuals and institutions. Rural regions, bearing the historical and traditional signs, created by the hard work of generations, provide wealthy heritage of a strong cultural identity. Local cultures stand for the source of activities, i.e. beneficial factor of the economic development of the areas (AEIDL, 1994).

Cultural routes (textile and crafts homemade products) may support the community existence (employment and income), for example, the women employed in textile production in Rethymno (Crete) in 30 independent, individual manufacturers, 2 smaller factories and 1 co-operative, where embroidery, weaving and sewing skills are used in production of embroidered items, handkerchiefs, bed covers, curtains, altar covers in various materials such as wool, cotton, silk and linen (Tzanakaki, 1999:80). The textile route confirms that each manufacturer belongs to a certain community. The local manufacturers, conscious of the lack of possibility for their individual promotion (or individual product promotion), distribute the advertising material on "Textile Routes" as a part of Eurotex Project. The programmes included in the cultural routes and offered by tour operators and tourist agencies have received positive opinion from the tourists (Roberts and Hall, 2003: 163).

The examples of such cooperation in Vojvodina with the aim of promoting cultural identity of a nation are the galleries in Kovačica. "Gallery of Naive Art" in Kovačica, founded in 1959 was the first rural gallery in the former Yugoslavia. Moreover, there is a privately owned gallery "Babka" by Pavel Babka that was pro-

Table 1 The number of people employed according to the type of activity in 1975, 1987, 1998. and 2000.

\begin{tabular}{|c|c|c|c|c|c|}
\hline Activity & & 1975. & 1987. & 1998. & 2000 \\
\hline \multirow{2}{*}{ INDUSTRY AND MINING } & Number & 174700 & 243617 & 178354 & 164198 \\
\hline & $\%$ & 35.5 & 39.0 & 40.1 & 39.7 \\
\hline \multirow{2}{*}{ AGRICULTURE AND FISHERY } & Number & 75000 & 66408 & 48463 & 44106 \\
\hline & $\%$ & 15.3 & 10.6 & 10.9 & 10.6 \\
\hline \multirow{2}{*}{ FORESTRY } & Number & 2800 & 2181 & 1783 & 1786 \\
\hline & $\%$ & 0.5 & 0.3 & 0.4 & 0.4 \\
\hline \multirow{2}{*}{ WATERPOWER ENGINEERING } & Number & 2500 & 2618 & 1963 & 1935 \\
\hline & $\%$ & 0.5 & 0.4 & 0.4 & 0.5 \\
\hline \multirow{2}{*}{ CIVIL ENGINEERING } & Number & 33300 & 42394 & 21835 & 19125 \\
\hline & $\%$ & 6.8 & 6.8 & 4.9 & 4.6 \\
\hline \multirow{2}{*}{$\begin{array}{l}\text { TRAFFIC AND } \\
\text { COMMUNICATIONS }\end{array}$} & Number & 27200 & 41252 & 26516 & 25046 \\
\hline & $\%$ & 5.5 & 6.6 & 6.0 & 6.0 \\
\hline \multirow{2}{*}{ TRADE } & Number & 44100 & 60510 & 30062 & 24596 \\
\hline & $\%$ & 9.0 & 9.7 & 6.8 & 5.9 \\
\hline \multirow{2}{*}{$\begin{array}{l}\text { TOURISM AND HOTEL } \\
\text { INDUSTRY }\end{array}$} & Number & 9600 & 13969 & 5706 & 4999 \\
\hline & $\%$ & 1.9 & 2.2 & 1.3 & 1.2 \\
\hline \multirow{2}{*}{ HANDICRAFT } & Number & 29100 & 18594 & 5779 & 4861 \\
\hline & $\%$ & 5.9 & 3.0 & 1.4 & 1.2 \\
\hline \multirow{2}{*}{$\begin{array}{l}\text { HOUSING-MUNICIPAL } \\
\text { ACTIVITIES }\end{array}$} & Number & 11600 & 8624 & 9519 & 9770 \\
\hline & $\%$ & 2.4 & 1.5 & 2.1 & 2.4 \\
\hline \multirow{2}{*}{$\begin{array}{l}\text { FINANCIAL AND OTHER } \\
\text { SERVICES }\end{array}$} & Number & 8900 & 22188 & 16642 & 15452 \\
\hline & $\%$ & 1.8 & 3.6 & 3.7 & 3.7 \\
\hline \multirow{2}{*}{ EDUCATION AND CULTURE } & Number & 32500 & 36725 & 38620 & 37924 \\
\hline & $\%$ & 6.6 & 5.9 & 8.7 & 9.2 \\
\hline \multirow{2}{*}{$\begin{array}{l}\text { HEALTHCARE AND SOCIAL } \\
\text { PROTECTION }\end{array}$} & Number & 2466 & 36205 & 39862 & 40316 \\
\hline & $\%$ & 5.0 & 5.8 & 9.0 & 9.7 \\
\hline \multirow{2}{*}{$\begin{array}{l}\text { ADMINISTRATION AND CIVIL } \\
\text { SERVICES }\end{array}$} & Number & 15500 & 28553 & 19126 & 19447 \\
\hline & $\%$ & 3.2 & 4.6 & 4.3 & 4.7 \\
\hline \multirow{2}{*}{ SUM } & Number & 491400 & 623838 & 444230 & 413556 \\
\hline & $\%$ & 100.0 & 100.0 & 100.0 & 100.0 \\
\hline
\end{tabular}

Source: Statistical yearbook of Serbia; 1976, 1988, 1999, 2000. Republic bureau of statistics, Belgrade.

claimed the world publishing centre for naive painting by UNESCO in 2001 (Ivkov, 2006). Ethno-centre "Babka", art galleries and houses of famous naive artists have been included in itineraries of international cruises on the Danube by tour operator Vantage Deluxe World Travel (half a day excursion within a fortnight package "Eastern Europe and the Black Sea", i.e. Danube cruise through Hungary, Croatia, Serbia, Bulgaria and Romania) (Vantage Deluxe World Travel, 2005).

Manifestation "Banat's precious hands", founded by the local Tourist Organization, comprises the tourist offer of the municipality of Zrenjanin highlighting the cultural heritage of the Banat population. Also the event is based on exhibitions and auctions of ethno items and various competitions concerning cultural issues:

1. Traditional food and beverages of the area;
2. Hand made items and household items - embroidery, different styles in needlework, wedding ornaments, etc.

3. Old crafts;

4. Customs;

5. Various ornaments - ornamented roof tiles, cattail dolls, ornamented courgettes, pictures made of straw, bast fibre hat, the pumpkin clock, glass brooches in the shape of insects, pictures made of dry flowers, paintings in wood, lamp made of rope, wood carvings.

6. Knowledge and skills of the people singing and oration.

The women associations, societies from various parts of the municipality (Gradnulica, Perlez, Aradac, "Vladimir Rolović", Ečka, Stajićevo, KUD "Petefi", Knićanin, Botoš, Melenci, Etno centar, MAKK "Mužlja”, KUD "Veseli Banaćani", "Savez slepih” - Zrenjanin, "Suncokreti”, Šumica, 
Table 2 Share of tourism and hotel industry in the number of persons employed in the economy of Vojvodina* in a period between $1972-2001$

\begin{tabular}{|c|c|c|c|c|c|c|c|c|}
\hline \multirow[t]{2}{*}{ Year } & \multicolumn{2}{|c|}{$\begin{array}{l}\text { Total number of people } \\
\text { employed in economy }\end{array}$} & \multicolumn{2}{|c|}{$\begin{array}{l}\text { Hotel Industry and } \\
\text { Tourism }\end{array}$} & \multicolumn{2}{|c|}{ Hotel Industry } & \multicolumn{2}{|c|}{ Tourism } \\
\hline & Total & $\%$ & total & $\%$ & total & $\%$ & total & $\%$ \\
\hline 1972. & 356017 & 100.00 & 8755 & 2.46 & 8590 & 2.41 & 165 & 0.05 \\
\hline 1973. & 360013 & 100.00 & 8716 & 2.42 & 8540 & 2.37 & 176 & 0.05 \\
\hline 1974. & 373569 & 100.00 & 8902 & 2.38 & 8703 & 2.33 & 199 & 0.05 \\
\hline 1975. & 391971 & 100.00 & 9220 & 2.35 & 9007 & 2.30 & 213 & 0.05 \\
\hline 1976. & 404399 & 100.00 & 9985 & 2.47 & 9750 & 2.41 & 235 & 0.06 \\
\hline 1977. & 418830 & 100.00 & 12484 & 2.98 & 12163 & 2.90 & 321 & 0.08 \\
\hline 1978. & 431504 & 100.00 & 12800 & 2.97 & 12478 & 2.89 & 322 & 0.07 \\
\hline 1979. & 447353 & 100.00 & 13128 & 2.93 & 12814 & 2.86 & 314 & 0.07 \\
\hline 1980. & 456368 & 100.00 & 13108 & 2.87 & 12708 & 2.78 & 400 & 0.09 \\
\hline 1981. & 468777 & 100.00 & 13124 & 2.80 & 12723 & 2.71 & 401 & 0.09 \\
\hline 1982. & 476940 & 100.00 & 13390 & 2.81 & 13016 & 2.73 & 374 & 0.08 \\
\hline 1985. & 528123 & 100.00 & 15951 & 3.02 & $\ldots$ & $\ldots$ & $\ldots$ & ... \\
\hline 1988. & 526772 & 100.00 & 13701 & 2.61 & 13191 & 2.50 & 510 & 0.11 \\
\hline 1989. & 525788 & 100.00 & 12802 & 2.43 & 12259 & 2.33 & 543 & 0.10 \\
\hline 1990. & 497589 & 100.00 & 11068 & 2.22 & 10910 & 2.19 & 472 & 0.03 \\
\hline 1991. & 461035 & 100.00 & 8961 & 1.94 & 8588 & 1.86 & 373 & 0.08 \\
\hline 1992. & 537484 & 100.00 & 8194 & 1.52 & 7862 & 1.46 & 332 & 0.06 \\
\hline 1993. & 425868 & 100.00 & 7388 & 1.73 & 7078 & 1.66 & 310 & 0.07 \\
\hline 1994. & 407363 & 100.00 & 6656 & 1.63 & 6350 & 1.56 & 306 & 0.07 \\
\hline 1995. & 389176 & 100.00 & 6353 & 1.63 & 6041 & 1.55 & 309 & 0.08 \\
\hline 1996. & 375459 & 100.00 & 6046 & 1.61 & 5782 & 1.54 & 264 & 0.07 \\
\hline 1997. & 356366 & 100.00 & 5955 & 1.67 & 5727 & 1.61 & 224 & 0.06 \\
\hline 1998. & 346588 & 100.00 & 5706 & 1.64 & 5464 & 1.58 & 242 & 0.07 \\
\hline 1999. & 329194 & 100.00 & 5293 & 1.61 & 5086 & 1.54 & 210 & 0.06 \\
\hline 2000. & 315845 & 100.00 & 4999 & 1.58 & 4810 & 1.52 & 186 & 0.06 \\
\hline 2001. & 290898 & 100.00 & 4890 & 1.68 & 4724 & 1.62 & 166 & 0.06 \\
\hline
\end{tabular}

Source: Statistical yearbooks of Vojvodina 1980-1989, Provincial bureau of statistics, Novi Sad and statistical yearbooks of Serbia 1990-2001. Republic bureau of statistics, Belgrade.

* Annual average calculated on the basis of two states ( $37^{\text {st }}$ March and $30^{\text {th }}$ September)

Dolja - Crni šor, Elemir, Centar) and independent exhibitors take part in competitions. The manifestation is held annually in June as a part of tourist event "Beer days" and lasts three days. (http://www.danipiva. co.yu/vest.asp?k=276).

"MIRK" - International exhibition of handicrafts and collections has taken part about thirty times at various locations in Vojvodina. Over 100 domestic and foreign exhibitors (from Hungary, Germany, Japan, Canada, Indonesia, and Bangladesh) participate every year. The exhibition comprises arts and crafts from all over the world, though the past and present handicrafts made by women make the blending of the old and new. The paintings, making wreaths, straw items, and precise arts such as ornaments made of goose egg shells are also found at exhibitions.

There are numerous ethno houses in Vojvodina Province, built either for special purposes or spontaneously by individuals or groups of individuals with the wish to cherish the remembrance and the spirit of the old times. Also, a significant number of those objects has been built for tourism purposes.

Ethno house in Jazak (Srem) was reconstructed by the Homeland Society "Teočin”. It was opened for public in 2003. The ethno house Jazak is furnished with the 19th century furniture items and houses the collections of national costumes from Srem, tapestry and embroidered bed sheets. The object renders traditional food and lodging dating back to the end of 19th century and beginning of 2 oth century. Special attraction is the opportunity to organize traditional wedding feast as celebrated one hundred years ago. The wedding ceremony takes place in the Jazak monastery and the traditional feast is organized in the ambience of the ethno house (Ivkov, 2006).

Ethno house in Maradik (Indija) was designed pursuing the initiative of Armida tours tourist agency. The house is over 200 hears old and comprises the yard, adja- cent objects, archaeological exhibition and ethno restaurant. It is of primary importance for the tourism of the municipality. The house is envisaged to enable visitors to learn about tradition, culture and ethnic heritage. It was built of mud and straw with all the necessary premises for a single household (rooms, kitchen, basement, storage room, barns and stables...). In all rooms and the house yard there are authentic objects; 50 to 200 years old. Within the ethno house, there is a mini ethno green market, where tourist can buy local products (honey products, various wines, seasonal fruit, milk products...) and try the authentic dishes and desserts of Srem (http://www.dnevnik.co.yu/arhiva/28-072004).

Colorful ethno house in Belo Blato (Zrenjanin). The project has been started under the name colourful ethno house. Apart from preserving the cultural heritage of numerous nations in this village, the project has been contributing to tour- 
ism development in the area where several languages are being used (Slovak, Hungarian, Bulgarian and Serbian). Ethno house should certainly contribute to the development of cultures and customs of those nations as well as to improvement in mutual tolerance. As the village is surrounded by the rivers Begej and Tisa, National reserve "Carska bara" and the lakes of fishing cooperative "Ečka", it has been awarded a significant position within the tourist offer of the area. (http://www.dnevnik.co.yu)

Romanian ethno house in Torak (Žitište) was opened in 2002. Its adaptation was financed by the Fund for ethnography and folklore of Romanians, Provincial and Municipal authorities, numerous donors and the Embassy of Romania.

Homeland ethno house "Délibáb" in Sajan (Kikinda) was founded on the proposal of the group of individuals. In 1993, the association "Délibáb" from Sajan commenced the project of collecting the objects used in households of their grandparents and great-grandparents in this village. The ethno house now comprises about 1,000 objects, the oldest of which dates back to 1876. The female members of the "Délibáb" association gather regularly in the house, especially on the occasion of holidays, conducting various activities (knitting, weaving, embroidering, etc.) and exhibiting their work (Varga, 2004).

Promotional activities for ethno houses in Vojvodina are inadequately conducted, thus the potential tourists lack the information on the houses, their position, accessibility, working hours, etc. Furthermore, the curators have not been employed in the houses and the promotional material has not been prepared yet.

Souvenirs, as the part of tourist product, may increase the employment opportunities for the local population. Souvenirs comprise various items that tourist purchase as the reminder of the place and attractions visited, i.e. to establish a connection between "here" (place of residence) and "there" (tourist destination). Souvenir is the proof of personal experience that connects us with acquired experience or different ways of life during the travel. However, souvenirs as the significant element of the tourist product in Vojvodina have not been properly recognized yet. It has been confirmed by the fact that the offer of ethno houses, the museums of national masonry and material and cultural heritage of the nation, lacks the souvenirs for sale (in most of the cases they have not been designed yet).

Within the framework of rural land changes and agricultural diversification, certain segments of tourism demand should focus on rural areas. The new form of rural tourism has developed from the continental, domestic or eco-tourism in rural areas. Out of the total tourist turnover in France the share of rural tourism was 370 million of tourist days in 1994 (or $27 \%$ of the global tourist travels) and $20 \%$ of the national tourism in France (Roberts and Hall, 2003:115). Thus, it was a step forward from wine tourism to general stays in rural areas. It also gave way to the new rural immigration attracted by the nature, by search for the authentic local community, or obsession with the past (the structure of collective imagination and urban population)

Gastronomy occupies the central position in the authenticity of the local culture, which is observable not only within the fact that national cuisine stands in the focus of tourist experience, but also through its source role in forming the national identity in most of the post industrial societies (Richards, 2001). National cuisine as a part of tourist product has grown into a contemporary and striking means of attracting tourist. It is a symbol of regional and local identities and the symbol of product quality.

National cuisine is a significant link between tourism and other economy branches, especially agrarian rural economy. It may also serve as an appropriate tool of rural development. As such, national cuisine needs to be integrated into other aspects of rural developments through complementary activities:

- Encouraging (initiation) innovations and complementing the reconstructed local agrarian economy (e.g. production and advertising of offer based on specialized meals including non-standard meals and organic food) (Bowen et al., 1991);

- Strengthening the cooperation of local small and medium enterprises oriented towards production and/or sale of food;

- Generating the welfare that would increase the value of the local community, obtained by production and development of retails (e.g. Sylvander, 1993);

- Increasing the food quality, creating positive attitude towards improvement and maintenance do the quality level in gastronomic tourist chain - both within production and consumer sectors (e.g. Gilg and Battershill, 1998; Ilbery and Kneafsey, 1998, 200oa,b);

- Strengthening the local and regional identities through the development and promotion of specific food brands at certain localities (settlements, regions, etc.) This enables the promotion of the local culture and heritage, for instance the food and wine routes. (e.g. Bessière, 1998)

The examples of successful revival and initiation of gastronomic offer within the present cultural offer of rural areas in Vo- jvodina certainly are authentic farms (salaš). ("Cvejin salaš", "Perkov salaš", "Majkin i Cvetni salaš", "Salaš 137", "Salaš 84 ", "Katin salaš", etc.).

\section{Conclusions}

The fact that population of Vojvodina becomes older faces tourist workers with a completely new task.

First of all, a larger number of young people, and of all those who are capable of working, should be included in the development of tourism in Vojvodina. Even older categories of population should be included as they could contribute to the development as much as they are able to (above all, taking care and nourishing of tradition). For instance, they could make national garbs, souvenirs (and other things of folk arts and crafts), or could be included in selling souvenirs and entrance tickets for tourist objects, or could be hosts (dressed in national garbs) who guests could take pictures with.

They can participate in the following services: car rent, taxi services, recreational services (horses, boats, bicycles, etc.) producers and retailers of craft products, food and drinks of geographical origin, etc. Those types of services are most frequently rendered by the local population, who occupies a significant role in creating a successful tourist product and deriving profit for the local community. In a large number of cases these jobs are of small capacity and owners need support and small amount of capital funds in order to start their own business (Wood Epler Megan, 2002).

That is a reason why we should, on a municipal level, develop tourist centers and make long-term plans connected with the development of tourism. Organize different courses for domicile population from smaller places in a municipality that has certain tourist potentialities (foreign language courses, computer courses, etc.), create spatial conditions, provide technical equipment and appliances, etc.

An additional income that enlarges earnings of a village household is achieved through old crafts and handiwork, thus producing different things made of wool, wood, reed, straw etc. that could be sold to tourists. In that way, a part of young population could earn in a village and thus indirectly prevent demographic discharging.

\section{Acknowledgement}

This article is a part of the project supported by the Ministry of Science and Environment Protection, Serbia (No. 146017).

\section{References}

AEIDL. 1994. Culture and rural development. LEADER Magazine 8. http:// www.rural-europe.aeidl.be/rural -en/ biblio/culture/arto5.htm 
Bessière, J. 1998. Local development and heritage: traditional food and cuisine as tourist attraction in rural areas. Sociologia Ruralis 38, 21-34.

Bowen, R. L., Cox, L. J., Fox, M. 1991. The interface between tourism and agriculture. Journal of Rural Studies 2(2), 42-54.

Gilg, A., Battershill, M. 1998. Quality farm food in Europe: a possible alternative to the industrialized food market and to current agro-environmental policies: lessons from France. Food Policy 23, 25-40.

Ilbery, B., Kneafsey, M. 1998. Product and place: promoting quality product and services in the lagging rural regions of the European Union. European Urban and Regional Studies 5(4), 321-341.

Ilbery, B., Kneafsey, M. 2oooa. Producer construction of quality in regional speciality food production: a case study from south west England. Journal of Rural Studies 16, 217-230.
Ilbery, B., Kneafsey, M. 2ooob. Registering regional speciality food and drink product in the United Kingdom: the case of PDOs and PGIs. Area 32(3), 317-325.

Ivkov. A. 2006. Folklorno nasleđe u turizmu Vojvodine. Zadužbina Andrejević, Beograd.

Kicošev S., Bubalo M. 1999. Strukture stanovništva. U: Stanovništvo Srema. Univerzitet u Novom Sadu, Prirodno-matematički fakultet, Institut za geografiju, Novi Sad.

Statistički godišnjaci Vojvodine 1980-1989, Pokrajinski zavod za statistiku, Novi Sad

Statistički godišnjak SR Srbije; 1976, 1988, 1999, 2000. Repulički zavod za statisti$\mathrm{ku}$, Beograd.

Sylvander, B. 1993. Specific quality product: an opportunity for rural areas. LEADER Magazine 3, 8-21.

Tzanakaki, K. 1999. Crafts tourism in Crete, Greece. In: Richards, G. (ed.) De- veloping and Marketing Crafts Tourism. ATLAS, Tilburg, pp. 73-87.

Vantage Deluxe World Travel 2005. Deluxe World Travel Vantage. 2006 European River Cruises Preview, Vantage Deluxe World Travel, Boston.

Varga. V. 2004. Zavičajna kuća "Délibáb" Sajan. U: Rumena jabuka. Etno i agro turizam Vojvodine. PČESA, Edicija Kulturno-istorijska baština Vojvodine, Novi Sad - Kulpin. Str. 250-251.

Wood Epler Megan, 2002. Ekoturizam. Principi, postupci i politike za održivost. Centar za odgovorni i održivi turizam, Beograd.

http://www.dnevnik.co.yu/arhiva/28-072004

http://www.dnevnik.co.yu 